\title{
The Effect of Subject Matter Analysis (SMA) on Knowledge in the face of the Out of Hospital Cardiac Arrest OHCA
}

Indonesian Nursing Journal of Education and Clinic (INJEC)

$\mid 47-15$ |

Volume 5, Issue 2, December 2020

DOI: 10.24990/injec.v5i2.306

injec.aipni-ainec.org/index.php/INJEC/index

Received : 2020-06-1I

Accepted : 2020-07-23

The Association of Indonesian Nurse

Education Center (AINEC)

\author{
Ria Anggara Hamba' ${ }^{(\mathbb{D}}$, Candra Kusuma Negara' ${ }^{\mathbb{D}}$, Abd Basid'
}

\begin{abstract}
Introduction: Out-of-hospital cardiac arrest (OHCA) is the focus of global health problems due to its very high mortality rate. The reason is the late reporting and administration of CPR (Cardio Pulmonary Resuscitation) actions. A solution is to provide CPR training in the community to form a CPR bystander who can be willing to voluntarily provide CPR actions. The purpose of this study is to analyze the effect of the Subject Matter Analysis (SMA) training model on knowledge in dealing with Out-of-hospital cardiac arrest (OHCA) events.

Methods: This study uses a Pre-experimental (One Group Pretest-Posttest) design using inclusion criteria. The independent variable in this study is SMA, while the dependent variable is the level of knowledge. The number of samples in this study was 50 s, one group without control group. The instrument used a knowledge level questionnaire. Measuring the BLS (Basic Life Support) recognition rate was by using a questionnaire; the data were analyzed using the SPSS for Window program with a dependent t-test.
\end{abstract}

Results: Based on what respondents answers there was a significant influence with the calculation of results showing $\rho$ value $=0.00 \mathrm{I}$ less than 0.05 .

Conclusion: This means that, after the posttest, there was an increase in the level of knowledge facing the OHCA event.

\section{Keywords}

analysis; cardiac arrest; subject matter

\section{INTRODUCTION}

Cardiac arrest, or called "Cardiac Arrest", is an emergency case that must get immediate treatment from medical personnel or the general public or a trained bystander. One treatment that must be given immediately is basic life support with cardiac pulmonary resuscitation (CPR). Late or improper treatment of cardiac arrest will have fatal consequences, namely internal death in minutes (Hazinski \& MD, 20I5).

The Centers for Disease Control and Prevention (CDC) survey in the United States found 31,689 cases of cardiac arrest for five years (2005-2010) and 33.3\% received CPR assistance from a bystander and 3.7\% using automated external defibrillators or AEDs

\footnotetext{
' High School of Health Science Cahaya Bangsa, Banjarmasin

Corresponding Author:

Ria Anggara Hamba, Department of Nursing, High School of Health Science Cahaya Bangsa, Banjarmasin, Indonesia Jl. A. Yani No.KM 17, Malintang Baru, Kec. Gambut, Banjar, Kalimantan Selatan 70122 Email: Riaanggarahamba@stikescb.ac.id
} 
Table I. Characteristics by Age of Respondents

\begin{tabular}{|c|c|c|}
\hline AGE & $\begin{array}{c}\text { Sample } \\
\text { (n) }\end{array}$ & $\begin{array}{c}\text { Presentace } \\
\text { (\%) }\end{array}$ \\
\hline$<20$ years & 2 & 4 \\
\hline 20-35 years & 7 & 14 \\
\hline $36-45$ years & 26 & 52 \\
\hline$>45$ years & 15 & 30 \\
\hline Elementary School & 3 & 6 \\
\hline Middle School & 6 & 12 \\
\hline High School & 32 & 64 \\
\hline Diploma/graduate & 9 & 18 \\
\hline
\end{tabular}

Table 2. Distribution of Central Value of Knowledge Level in the face of OHCA Events Before and After the High School Training Model is given

\begin{tabular}{clccccc}
\hline No. & Variable & Mean & Median & SD & T & P Value \\
\hline 1. & Before & 1.91 & 2 & 0.648 & 3.634 & 0.001 \\
2. & After & 1.62 & 2 & 0.724 & & \\
& Difference & 0.29 & & 0.076 & & \\
\hline
\end{tabular}

(Bryan, 2010). About 360,000 cardiac arrest events are found outside the hospital each year and $15 \%$ is the cause of all deaths. The prevalence of cardiac arrest in Indonesia every year has not obtained clear data, but the prevalence of heart disease in Indonesia is $7.2 \%$ (Sasson, 2013). According to the South Kalimantan Provincial Health Office, in particular the city of Banjarmasin,, there is also no data on cardiac arrest but in 201 the prevalence of heart disease was found to be 8.1\% (Range I.7-I2.7\%) (RSUD ULIN, 20I0).

Concerning heart failure, as many as $0.1 \%$ are at risk of having a heart attack and cardiac arrest (Pranata, 20I3). Cardiac pulmonary resuscitation (CPR) is part of basic life support that helps the heart function again as a pump and improve blood circulation in the body. Basic life support can be done by anyone and anywhere as soon as possible at the onset of a cardiac arrest to increase survival rates (Subagyo et al., 201 I).

Many cases of heart attacks that cause death, begin with symptoms first, such as typical chest pain, shortness of breath, swelling in the legs, even convulsions. Basic life support uses the concept of life chains (Chain of Survival) consisting of early recognition and immediate access, pulmonary resuscitation, immediate defibrillation using AED
(Automated External Defibrilator), and immediate follow-up care (Subagyo et al., 20II).

Basic Life Supports (BLS) should be given to victims who experience breathing arrest, cardiac arrest, and bleeding. BLS skills can be taught to anyone, especially every adult should have BLS skills (Frame \& Scott, 20I0). Therefore education and training on basic life support is important to be given to ordinary people as the first helper (Suharsono \& Ningsih., 2008). Based on the above problems, the researcher would like to investigate further on the effect of the Subject Matter Analysis (SMA) training model on knowledge in the face of OHCA (Out of Hospital Cardiac Arrest) incidents in $\mathrm{TKCl}$ (Toyota Kijang Club Indonesia) Banjarmasin area.

\section{MATERIALS AND METHODS}

This study uses a pre-experimental (One Group Pretest-Posttest) design using inclusion criteria: a. can communicate well, b. do not have health problems. Measuring the level of BLS knowledge used a knowledge level questionnaire. The population in this study were all members of the Banjarmasin $\mathrm{TKCl}$ car club community, as many as 50 people. The sample in this study were all community 
members by taking total sampling. Samples were first given a knowledge questionnaire about BLS then BLS training for evaluation and were then given the same questionnaire and then analyzed to see if there was any change. Data were analyzed using the SPSS For Window program with a dependent t- test. This research has been tested by the Ethics Commission of Ulin Hospital with No.354 / IIReg Research / RSUDU / 20.

\section{RESULTS}

Based on Table I it can be seen that respondents aged 36-45 years are 26 people (52\%). Also it can be seen that the majority of respondents have a high school education level of 32 people (64\%).

Based on table 2, from the dependent ttest before being given the High School Training Model, the average value (mean) of I.9I was obtained with a standard deviation of 0.648 and a median value (median) 2. After being given the High School Training Model, the average value was obtained (mean) 1.62 with a standard deviation of 0.724 and a median value (median) 2. It can be seen that the mean difference before and after back massage therapy is 0.29 with a standard deviation, a $\mathrm{t}$ value of 3.634 , and a significance value of $0.00 \mathrm{I}$.

\section{DISCUSSIONS}

Cardiac arrest is an emergency case that must get immediate treatment from medical personnel or the general public or a trained bystander. One treatment that must be given immediately is basic life support with cardiac pulmonary resuscitation (CPR). Late or improper treatment of cardiac arrest will be fatal, that is, death within minutes. Knowledge is a result of knowing from humans for the merging or cooperation between a knowing subject and a known object; all that is known about a particular object. (Trivener \& Gloe, 2015). This is supported by the opinion of Wawan and Dewi (20l I) that training is a part of non-formal education to be able to find knowledge. Someone who gets training will get experience related to the knowledge gained from the training. Experience can be related to age and education, such as higher education will have more extensive experience and the older they are then the more experience someone has.

AHA (20I5) recommends a solution to the high incidence of OHCA, namely by increasing the role of everyone in the community to become A CPR bystander. CPR that is carried out quickly will increase the survival rate of OHCA victims by two to three times (Hazinski \& MD, 2015). The number of CPR bystanders in various countries, especially in developing countries, such as in Southeast Asia, is still very small. Efforts that can be made to increase the number of CPP bystanders are by providing training to the community on how to take appropriate CPR actions (Wang et al., 2015).

The SMA training model is a training model where, at the beginning of the training activity, the intensity of the trainer's role is high. This role is shown in assisting participants by presenting information about teaching materials (training materials) and by conducting motivation and guidance to participants. The intensity of the trainer's activities (source) is increasingly decreasing so that the role is more directed to monitor and provide feedback on training activities, and vice versa, participants' activities at the beginning are of low activity; this initial activity is used only to receive training materials, information, instructions, materials, activity steps, etc. Then, community participation is increasingly rising and actively building a more meaningful training atmosphere.

When respondents were given a high school training model, it was found that $38 \%$ (19 respondents) had good knowledge, 62\% (3I respondents) had sufficient knowledge and $0 \%$ (0 respondents) had less knowledge. From these data, it can be seen that there was an increase in respondents' knowledge after being given a High School Training Model in dealing with OHCA events. This is supported by Bertnus (2009) that the factors that can affect skills are knowledge, experience, and desire / motivation. An individual must have certain factors that can affect skills; this is related to the actions that must be taken to build a good skill. These skills can be obtained from education and training. These skills must always be improved / developed and maintained so that people who have attended training and are already skilled can help people whose heart stops and stop breathing. 
Based on the results of statistical tests, obtained $\rho$ value $=0.00 \mathrm{I}$, thus it can be concluded that, in this study, there is a significant influence between the High School Training Model (Subject Matter Analysis) on Knowledge in Facing OHCA (Out of Hospital Cardiac Arrest) Events in the $\mathrm{TKCl}$ Community (Toyota Kijang Club Indonesia ) Rayon Banjarmasin.

The above results are in line with research conducted by Chaudhary et al. (20II) who explained that an increase in CPR skills can be done by attending BLS training. Continuous training is needed for refreshing knowledge and skills. Keenan et al. (2009) explained that refresher training must be done every 6-12 months to maintain the ability of BLS skills; this is because a person's skills about BLS, especially CPR, can decrease after two weeks of training, and the results of other studies conducted by Kuhnighk, Sefrin, and Paulus (2005) on skills and self-assessment in pulmonary resuscitation from hospital employees, the results showed that $36 \%$ of hospital staff were skilled enough from 425 respondents. The management of traffic accident patients is not only limited to the provision of CPR assistance, for stable patients there are several nursing diagnoses, one of them is pain due to fracture and research conducted by Negara (2019) shows that music therapy can reduce the pain of fracture patients. Here, nurses can do nonpharmacological interventions.

The knowledge possessed by cadres about BLS is very influential in the skills in performing recovery position as seen from the number of respondents who are well-knowledgeable and skilled. This is supported by the theory put forward by Andersson and Olsson (2006) that good knowledge is very influential on good skills as well. The skill or ability of a person to apply the knowledge possessed in the form of actions where an individual who finds a victim whose heart stops and stops breathing can do BLS by giving CPR and performing recovery position actions when the victim has a pulse and breathing to prevent airway obstruction. Research results conducted by the researchers are currently in line with research by Alhidayat, Rahmat, and Simunati (2013) where the results of these studies indicate a high level of nurse knowledge influencing skills or high implementation with a $\mathrm{p}$ value $=0.004$.

\section{CONCLUSION}

This means that, after the posttest, there was an increase in the level of knowledge facing the OHCA event. Implications for the research are expected to request this model from other communities, such as motorcyclists and other social communities, because this training is very important and very useful.

\section{Acknowledgement}

We would like to thank the participants who have helped in this research and the research sites that have facilitated this research.

\section{Conflict of Interest}

All the authors have no conflict of interest related to the study.

\section{REFERENCES}

Andersson, M., \& Olsson, U. (2006). Coping Strategies in Conjunction with Amputation Coping strategier i samband med amputation. January, $23 . \quad$ http://www.divaportal.org/smash/get/diva2:5930/FULLTE XTOI.pdf

Bertnus. (2009). Faktor yang Mempengaruhi Keterampilan. (sitase).

Chaudhary, Parikh, \& Dave. (20II). Current scenario: Knowledge of basic life support in medical college. Nat J Med Res, I, 8.

Frame, \& Scott, B. (20I0). Basic and Advanced Prehospital Trauma Life Support. First Aid in Illness and Injury; Traumatology.

Hazinski, M. F., \& MD, M. S. (20I5). American Heart Association.

Keenan, M., Lamacraft, G., \& Joubert, G. (2009). A Survey Of Nurse Basic Life Support Knowledge and training at a tertiary hospital. African Journal of Health Proffesions Education, I (I), 4-7.

Kuhnighk, H., \& P, S. (2005). Skill and Self assesment in cardio-pulmonary resuscitation of the hospital nursing staff.

Negara, C. K., Murjani, A., Martiana, A., \& Kurniawan, F. (20/9). Guided Imagery Using Classical Music on The Reduction in Pain Level of Fracture Patients. INDONESIAN NURSING JOURNAL OF 
EDUCATION AND CLINIC (INJEC), 4(I), 4347.

Sasson, C. (20/3). Increasing Cardiopulmonary Resuscitation Provision in Communities with Low Bystander Cardiopulmonary Resuscitation Rates Circulation. 127, I-9. https://doi.org/DOI:10.1 I6I/CIR.0b013e3 I8288b4dd.

Subagyo, A., Achyar, E, R., Sugiman, T., Kosasih, A., \& Agustinus, R. (20I I). Buku Panduan Kursus Bantuan Hidup Jantung Dasar. Perhimpunan Dokter Spesialis Kardiovaskular Indonesia.
Trivener, K., \& Gloe, D. (20I5). The Effect of High Fidelity Cardiopulmonary Resuscitation (CPR) Simulation on Athletic Training Student Knowledge, Confidence, Emotions, and Experiences. Athletic Training Education Journal, 10(2), 104-II2.

Wang, J., Ma, L., \& Lu, Y. (20I5). Strategy analysis of cardiopulmonary. Journal of Thoracic Disease, 7(7), 160-165.

Wawan, A., \& Dewi, M. (20II). Teori dan Pengukuran Pengetahuan, Sikap dan Perilaku. Muha Medika. 